\title{
Qur'anic Words: An Analysis on Shihab's Rules of Exegesis in Tafsir Al-Mishbah
}

\author{
Ahamad Ahmadi Sakat ${ }^{2}$ \\ Abur Hamdi Usman ${ }^{1}$ \\ Muhammad Masruri4 \\ Mohd Fauzi Mohd Amin ${ }^{3}$ \\ Mohd Nazri Ahmad² \\ Muhd Najib Abdul Kadir2

\begin{abstract}
${ }^{1}$ Department of Usuluddin with Multimedia, International Islamic University College Selangor, Malaysia
Corresponding Author Email: aburhamdiusman@yahoo.com

2 Faculty of Islamic Studies, The National University of Malaysia, Malaysia

${ }^{3}$ Faculty of Quranic and Sunnah Studies, Islamic Science University of Malaysia, Malaysia

${ }^{4}$ Institute of Islam Hadhari, The National University of Malaysia, Malaysia
\end{abstract}

\section{Doi:10.5901/mjss.2015.v6n4s1p454}

\section{Abstract}

Shihab is an Islamic scholar who has prolifically produced a comprehensive 30 chapters of Qur'anic exegesis entitled Tafsir AlMishbah. This book is perceived as the latest Qur'anic exegesis produced by Muslim scholar of the Archipelago. He stresses on the importance of understanding the Qur'an contextually, supported by a strong understanding of the language and not focusing only on the textual meaning. In relation to this, his work has used a lot of linguistics approaches as to obtain the actual verses exegeses. Therefore, this study seeks to analyse critically his linguistics exegesis, and the focus rests on the debate on Qur'anic words. To obtain an explicitness perspective, this study has adopted the library research and document analysis method by making language and reliable popular Qur'anic exegesis books as primary sources of reference. The outcome of this study finds that Shihab had applied five rules in relation to Qur'anic words, all of which have been approved by scholars and exegetes. In addition, this study also found that Shihab absolutely consistent in applying these rules, except in the first rule. By doing so, it was slightly crippled his exegetical work. Finally, this study suggests that it is not possible that a grammatical error occurs in the Qur'an. Indeed, the essence of the Arabic language rules is unparalleled with the structure of the Qur'an, but the arrangement rule was implemented after the Qur'an was revealed. If both cannot be made consistent with one another, then this is due to the limitation of method which is known as shādh.

Keywords: Shihab; Tafsir Al-Mishbah; Exegesis; Rule; Words; Indonesia

\section{Introduction}

Making an effort to understand the Qur'anic meaning was constantly attract the attention and interest of Muslim and nonMuslim scholars till today. The Qur'an is the most attractive object of study due to its position as a major source of Islamic laws. Even all the problems faced by Muslims can be sought its solutions through the Qur'an. Consequently, the development of Qur'anic exegesis with various methodologies should be balanced with Qur'anic knowledge tools, such as mastery of the rules of exegesis. This is to ensure the exegetes could comprehend the Qur'an holistically. Therefore, mastering the rules of exegesis is a necessity to ensure Qur'anic meanings could be justified scientifically.

One of the important rules in interpreting the Qur'an is to consider the meaning that indicated by the words. Muhammad (2009) asserts that an exegete should care about the meanings contained by the Qur'anic words. As a result, al-Sa'di (1999) argues that the main basis of the most useful is to understand what is indicated by the words from the diversity of meanings. A person must understand this method carefully, and then rethink about any things that could be collaborated with its meanings. Thus, one cannot interpret the Qur'an properly if ignore this advice.

Hence, in this vein, this decent article focuses on the study on the rules of exegesis employed by M. Quraish Shihab (Shihab is used in place of his full name) in his work Tafsir Al-Mishbah that relates with the diversity meanings of Qur'anic words. To get a better explanation, by applying document analytical approach, this study only discusses on the 
rules of exegesis and its level of validity which applied by Shihab in his exegetical work, Tafsir Al-Mishbah. However, to gain perfect comprehension, this study begins to discuss on Shihab's brief biography and the rules of exegesis terminology and its function. Methodically, to strengthen the findings, all materials collected and analysed by adopting content analysis method; where the main source is Tafsir Al-Mishbah which supported by other materials, such as books, journals, dissertation, thesis, etc.

\section{Shihab: A Biographical Highlight}

Shihab was born in Rappang, South Sulawesi on $16^{\text {th }}$ February 1944. His early education was obtained from his father, Abdulrahman Shihab. His love towards the Qur'an blossomed from the age of six (Shihab, 1992). As a son of a famous exegete, he was often brought by his mother to attend religious classes given by his father. His mother also sparked his interest, as her constant encouragements and guidance resulted in his decision to further his studies in the same field (Naja, 2007). Other than his parents' early involvements at home, he also studied at Pondok Pesantren Darul Hadith alFaqihiyyah, Malang. Soon after, in 1958 the state of Sulawesi awarded him a scholarship to study at the University of alAzhar, Cairo, Egypt, and he was accepted to move up to grade two thanawiyyah al-Azhar. His academic journey later took him to the Department of Theology, University of al-Azhar majoring in Tafsir and Hadith. He completed his bachelor degree in 1967. Two years later in 1969, he managed to obtain a master degree in the same field (Shihab 2011a).

In 1980, Shihab furthered his Ph.D degree in the same university. He completed his study in two years and obtained mumtaz ma'a martabah al-sharaf al-ula grade (an exemplary scholar with outstanding performance). His outstanding results qualified him as the first South East Asian student to obtain a Ph.D degree in Qur'anic sciences from al-Azhar University (Subhan, 1993). The process of intellectual growth experienced by Shihab for 13 years at the University of al-Azhar shaped his form of thought. In addition, he is also known as a religious figure, educator and also has his own publication house, Lentera Hati Publisher. Furthermore, Al-Darraz (1991) has stated that a scholarly work could not escape seven points, namely: a totally new article, completing the incomplete, explaining the vague and difficult, summarizing the long, updating the mixed, purifying the wrong and collecting the scattered. According to lbrahim and Usman (2013a.) Shihab does all these things well, and even links the limitations which often happen when someone wants to clarify the terms of Islamic scholarship in Arabic into Indonesian language quite successfully. Therefore, there is no doubt that this Indonesian scholar is named a credible and respectable expert in the Qur'anic exegesis.

Shihab is able to connect his ideas to the readers well proven with several of his books reprinted several times as well as becoming best sellers. One of his works entitled Tafsir al-Amanah and Membumikan al-Qur'an: Fungsi Wahyu dalam Kehidupan Masyarakat obtained appreciation as the most in demand books in 1993 published by Mizan Publication (Subhan, 1993). His academic works published for the public are in analytic and global exegesis. Shihab began his writing with applying this method in 1986 (four years after completing his Ph.D) until 2008 with six publications.

Other than that, he wrote books pertaining to the thematic exegesis from 1991 until 2011 with fourteen works published. It is an indicator that the approach applied is continuously practiced in all his works. He also wrote books pertaining to Islamic knowledge in general. Based on the books reviewed, Shihab's career in writing on general Islamic knowledge from 1984 until 2011 with sixteen publications altogether. In addition, Shihab's writings in the field of religious issues were also evident. He is very much careful in producing works related to legal opinion (fatwa) or providing answers pertaining to religious doubts. He often rejects tasks in managing activities relating to fatwa. He requests them to be handled by others who are more knowledgeable in the said field. But due to ample requests by many as well as encouragements obtained from friends and the fear of accusations of hiding knowledge, he finally agreed to fulfil the responsibility whole heartedly (Shihab, 2011b).

Shihab's magnum opus in exegetical work is Tafsir Al-Mishbah as well as dozens of other books. This book is perceived as the latest Qur'anic exegesis produced by Muslim scholar of the Archipelago. It is a complete exegesis consists of 30 parts and 15 volumes. It is written when he was Ambassador of the Republic of Indonesia in Egypt and is completed after four years. It started in Cairo on Friday 18 June 1999 and finished in Jakarta on Friday, 5 September 2003 after spending approximately seven hours per day (Ibrahim \& Usman, 2013b.).

\section{The Rule of Exegesis: Definition and Function}

Shihab is very concerned about the importance of language in interpreting the Qur'an. He states that in order to understand the Qur'anic content, in-depth knowledge of the Arabic language used in the Holy book is pivotal. It can help one understand the meaning of each word in a verse, where one shall first review the meaning in the word and then set the most appropriate meaning after analysing all aspects relating to the verse. This approach is used consistently in each 
verse he analysed. He was very attentive to the vocabulary meaning or the Qur'anic expressions with reference to the opinions of the language experts. In addition, he always questioned how the vocabulary is used in the Qur'an (Ibrahim \& Usman (2013c.).

The rules of exegesis in Arabic language is a combination of two words namely qawāid (rules) and al-tafsir (exegesis). Qawā'id in the language viewpoint according to al-Kafawī (1998) defined it as pillars for everything above it, whereas the rule terminology according to al-Sabt (2001) defined it as a general stipulation by which provisions associated with the details were known.

The definition of al-tafsir from the aspect of language according to al-Jurjānī (1985) is explaining something and making it clearer and more distinct, or uncovers something hidden. However, in terms of terminology, al-Zarkashĩ (1988) defined it as a set of knowledge employed to have the best understanding of the Qur'an which was revealed to the Prophet (pbuh), clarifying its meaning, extracting rulings of Islamic law and wisdoms contained in it with the aid of linguistics, Arabic grammar, Principles of Jurisprudence, reasons of the revelation, and the abrogation and abrogated.

Based on these definitions, it can be concluded that what is meant by the rule of exegesis is a set of ruling which is universal in nature, used by exegetes as a guideline to reach to the study of the meanings of the Qur'an and knowing the procedures to get its wisdoms.

\title{
4. The Rule of Qur'anic words: Reviews of Semantics and Its Application
}

In line to the notion of the rules of exegesis, as the best tool to ensure one's exegeses does not deviate, Shihab as one of the exegetes in the Archipelago also applied some rules which accordance to Qur'anic words, such as:

\subsection{RULE: Interpreting the Qur'an by the most popular and well known Arabic language and most eloquent rather than the odd or rare meaning.}

This rule as mentioned by al-Sabt (2001) due to the Qur'an was revealed with fluent and best of Arabic, then its interpretation banned with the strange and isolated meaning and leave the most popular and well-known meaning. This rule is also supported by Ibn al-Wazīr (1987) in his book Ithär al-Haq.

Shihab (2010) applied the rule above when interpreting sura Äli Imrān (Family of Imran) verse 45:

\begin{abstract}
"[And mention] when the angels said, "O Mary, indeed Allah gives you good tidings of a word from Him, whose name will be the Messiah, Jesus, the son of Mary - distinguished in this world and the Hereafter and among those brought near [to Allah ]."
\end{abstract}

Shihab (2010) has declared two meanings of the word al-Masīh, it taken from masaha which means to wipe. The excerption from the New Testament, Luke VII-36 was supported this meaning. And the second meaning is touring or nomadic, because the Prophet Jesus known often moves from one place to another to invite people to the right path. ${ }^{1}$

The both meanings above specified by Shihab (2010) are based on the famous linguistics meaning used by the Arabs and not the unknown meaning or Shādh (Mazlan \& Abur, 2013c). This was also specified and chosen by al-Tabarī (2001) and Ibn 'Atiyyah (2001) in their books. However, the study found that there was times when Shihab (2010) did not use the rule above when interpreting sura Âli Imrān (Family of Imran) verse 27 as follows:

"You cause the night to enter the day, and You cause the day to enter the night; and You bring the living out of the dead, and You bring the dead out of the living. And You give provision to whom You will without account."

Shihab's interpretation to the phrase "And You bring the living out of the dead, and You bring the dead out of the living" was found using a meaning which is not commonly used by the Arabs. When Shihab (2010) was interpret he quoting classical scholars view stating that "Life and death either on real (haqīi $)$ or metaphorical (majāzī) meaning, Allah has replaced between the two. He brings forth the living from the dead and the dead from the living. From a believer whose heart was alive, born a non-believer whose heart is dead and vice versa. So many non-believers whose heart is dead gave birth to the devout son and daughter. From inanimate objects such as eggs, born a living chicken, and from a living object like chicken, born eggs. ${ }^{2}$

These excerpts show that Shihab accepts all meaning contained in the phrase above, whether real or metaphorical

\footnotetext{
1 See also Shihab's exegesis that applied this rule in sura al-Balad (The City) verse 3.

${ }^{2}$ See also Shihab's exegesis that does not applied this rule on a word wajīhan in sura Āli 'Imrān verse 45.
} 
meaning. However, his tendency was more focused on metaphorical meaning, such as the following Shihab's statement "That now through genetic process, many plants or live animals such popular creature are known, their life is sourced from something that was considered dead. Thus, Allah produces the life from the dead and vice versa".

Shihab's statement clearly shows that the meaning "And You bring the living out of the dead" is that life resulting from inanimate objects through genetic methods. Therefore, the meaning is not popular. Accordingly, alQaraḍāwī (2001) stated that basically needs to be known is interpretation of the verses must follow the real meaning and not to the metaphor, except with three kinds of indicator (qarīnah majāz). If not, then there should be no further discussion. ${ }^{3}$ Consequently, Ibn 'Ațiyyah (2001) and al-Qurțubī (1964) for example, tend to interpret the above verse with real meaning even it is also the opinion of the majority of scholars, although they differ in opinion on the corner of analogy.

Al-Tabari (2001) notes that from the various interpretations of the relevant verse above, the correct interpretation is human life as well as animals were issued from the death sperm (meaning brings the living from the dead), and then to produce the death sperm from human life, as well as animals (that's what brings out the dead from the living). Because every living things could be left by one of their body parts, and considered as mayyit or the dead. Thus, the sperm can be considered as mayyit also. Due to the sperm confirms itself from the body when separate, then Allah growing it and becomes a human being. This issue was happening also to the animals. Similarly this meaning includes to every creature that left by something from its body and called as mayyit (this meaning consistent with Allah's word in Sura al-Baqarah (The Cow), verse 28). The interpretation of sura Âli Imrān verse 27 states that seed coming out on stalk and vice versa, eggs from chickens and vice versa, as well as mukmin of infidelity and vice versa, though understandable, but it is not commonly used in Arabic outwardly. While understanding the Qur'an with exoteric meanings that are commonly used outer Arabs more important than who understand the meaning of vague and rarely used.

Based on the above explanation, can be concluded that the Shihab's interpretation in sura Âli 'Imrān verse 27 tends to lump the metaphor meaning which is strange and isolated, though can be construed with the real meaning. Shihab's tendency to this rule causes his interpretation conflict with great exegete, such as al-Tabari (2001), alQurțubi (1964) and Ibn 'Ațiyyah (2001) who interpret the true meaning of the verse and with the popular and well-known Arabic language.

\subsection{RULE: Do not interpreting the Qur'anic meaning by a new term}

Among the scholar who described this rule is al-Sabt (2001). In relation with it, Riḍa (1990) states that interpret the Qur'an with linguistic approach should pay attention to the meaning contained by the verse harmonize and the meaning that understood in the period of Qur'an was revealed and not with meanings that evolved later along with the linguistic development.

Al-Rūmī (1999) also noted other methods that support the use of the above rules, which means that the meaning of Islamic law takes precedence over the language meaning. This is due to the Qur'an was revealed to explain the legislation, not the language, unless there is indicators to the contrary (Al-Zarkashī 1988). Hence, when the exegete find a verse only can be interpreted with the meaning of the language, then the rule proposed by al-Sabt (2001) above must be taken into account.

Al-Qaraḍāwī (2001) also noted that the language which becomes a reference is known at the time of the revelation of Qur'an as well as the expression which shown by various words at the time. Rather than the meaning of language that has developed after that, as the progress of science and knowledge, international interaction and mixing of civilization with other civilizations, the influence of tradition, terms and other factors. All may give new meaning to the words that is not available at the time of the Prophet (pbuh). Therefore, the meaning cannot be used to understand the Qur'an.

Shihab (2010) for example, has applied the above rule when interpreting sura al-Tawbah (The Repentance) verse

\footnotetext{
3 The three metaphorical indicators (qarīnah majāz) were meant by al-Qaraḍāwī, namely: (i). The nature of reasoning (al-'aqliyyah), which can be known by the addresser and addressee, as Allah says about the word part of Prophet Joseph brothers to their another brothers in sura Joseph verse 82: "And ask the city in which we were and the caravan in which we came - and indeed, we are truthful" The city (al-qaryata) means those villagers. The meaning can be understood easily, because there is no difficulty for Arabs to understand the meaning of this word. (ii). The nature of tradition (al-'urfiyyah), as Allah says about the word of Pharaoh in sura Ghāfir (The Forgiver) verse 36 below: "And Pharaoh said, O Haman, construct for me a tower that I might reach the ways" The word Haman means an instruction to the people to build a tower, due to Haman who could not construct any building based on the tradition. (iii). The nature of word (al-lafziyyah), as Allah says in sura al-Nür (The Light) verse 35: "Allah is the Light of the heavens and the earth. The example of His light is like a niche within which is a lamp, the lamp is within glass..." The word light (nür) in this verse is a proof that God is not the light, but a Guider, as illustrated by the next verse: "Allah guides to His light whom He wills...".
} 
3 in the following:

"And [it is] an announcement from Allah and His Messenger to the people on the day of the greater pilgrimage that Allah is disassociated from the disbelievers, and [so is] His Messenger. So if you repent, that is best for you; but if you turn away - then know that you will not cause failure to Allah. And give tidings to those who disbelieve of a painful punishment."

Shihab (2010) states that the phrase in verse yawm al-haj al-akbar (the day of the greater pilgrimage) its meaning has been debated by scholars after they agree that happened in the ninth year of Hijrah on the day of the pilgrimage. Haji held in Muharram is called al-haj al-akbar (major pilgrimage), while umrah which practicable throughout the year named al-haj al-āssghar (minor pilgrimage). One understands that the announcement was implemented during the days of the pilgrimage (start the $8^{\text {th }}$ to $13^{\text {th }}$ ), this is the opinion of Sufyān al-Thawrī.

There is another view that the announcement was only in one day, on the day standing at Arafat on the $9^{\text {th }}$ Muharram, this is the opinion of Abū Ḥanīfa and al-Shāfi'T. While Mālik, al-Tabarī and al-Bukhārī believe that the announcement is carried on the day of nahar, the first day of sacrifice on the $10^{\text {th }}$ Muharram. Based on these differences, all the opinions associated al-haj al-akbar with the implementation of the pilgrimage, whether it is intended to wukuf day, the sacrifice or even the days of the haij. Therefore, al-haj al-akbar occurs every year. Not as prevalent opinion among people who understand the standing at Arafat accepted on Friday. Not found any opinion of the scholars who understand the meaning of al-haj al-akbar as understood by the community today. ${ }^{4}$

Based on Shihab's interpretation above it can be understood that all differences of scholars opinion regarding the word of al-haj al-akbarwere associated with the implementation of the pilgrimage, whether it is intended on day of wukuf, ${ }^{5}$ sacrifice, ${ }^{6}$ or even in the days of the hajj. Therefore, al-haj al-akbar can happen every year and not as prevalent opinion was voiced in the community that it occurs when standing at Arafat on Friday. In fact not found the opinion of a scholar who understands the meaning of al-haj al-akbar as understood by the Muslim community today. Accordingly, the study found that this interpretation is also stated by al-Shawkānī (1993) in his book Fath al-Qaḍīr.

In addition, to reinforce the use of the above rules, it is worth to recognize Shihab's statement to the rules was described. Shihab (2011) stated that understand the Arabic vocabulary with meanings that have been developed after the revelation of al-Quran is not allowed, such as Sura al-Rüm (The Roman) verse 55 in the following:

"And the Day the Hour appears the criminals will swear they had remained but an hour. Thus they were deluded"

Shihab (2011) states that we cannot understand the meaning of the word sa'ah (one hour) to "sixty minutes", due to sa'ah is not recognized in the time of the revelation of the Qur'an ago.

\subsection{RULE: The word 'asā in the Qur'an when referred to Allah contains the meaning of certainty and if referred to others it means guidelines for hope and optimism.}

Among the scholar who specified this rule is al-Zarkashī (1988) and could be easily understood its purpose when Shihab (2010) applied it in sura al-Mumtahanah (She that is to be examined) verse 7 below:

"Perhaps Allah will put, between you and those to whom you have been enemies among them, affection. And Allah is competent, and Allah is Forgiving and Merciful".

Shihab (2010) states that the word 'asā used to describe expectations about something happening in the future. Surely this is impossible for God because everything knew by Him. Therefore, the word 'asā referred to the addressee, means 'expect and optimist'. Some scholars argue that all the word of 'asā in the Qur'an contain the meaning of certainty. According to Shihab's research, this opinion is right if it expressly attributed to Allah, like the verse above. But if it is not referred to Him, it means the guideline to always be hope and optimism as shown in sura al-Baqarah (The Cow)

\footnotetext{
${ }^{4}$ See also Shihab's exegesis that applied this rule in suras al-Māidah 5: 3, al-A'rāf 7: 88, 104, 108 \& 199, al-Anfāl 8: 50, al-Haj, 22: 47, al-Mu'minūn 23: 100, al-Sajdah 32: 4, Fāțir 35: 28, Yāsin 36: 20, Fușșilat 41: 9, al-Jāthiah 45: 16, al-Raḥmān 55: 29, al-Ma'ārij 70: 4, alMuzzammil 73: 14, and al-Qadr 97: 2.

${ }^{5}$ The narration as cited by Ibn Kathir (2000) in the following: Narrated by Ibn 'Umar: On the Day of Nahr (10th of Dhul-Hijja) the Prophet stood in between the Jamrat during his Hajj which he performed and said: "This is the greatest Day (i.e. 10th of Dhul-Hijjah)."

${ }^{6}$ The narration as stated by al-Tirmidhi (2008) in the following: "It was narrated from Ali when he asked the Messenger of Allah (pbuh) about the Day of Sacrifice. The Prophet (pbuh) said: "This is the day of the greatest Hajj".
} 
verse $16 .^{7}$

Hence, based on the Shihab's exegesis above it is understandable that the word 'asā in the Quran contains the meaning of certainty (al-ta'kid) if pegged to Allah (al-Shanqiți 1995). And if in addressed to others, it means hope and guidance to be optimistic (Riọā 1990) as shown in sura al-Baqarah verse $16 .{ }^{8}$

\subsection{RULE: When the command of obedience to Allah and His Messenger, compiled in one word, it means the obedience commanded by Allah and vice versa.}

The clearest example to understand this rule ${ }^{9}$ when Shihab (2010) interpreting sura al-Nisā' (The Women) verse 59 below:

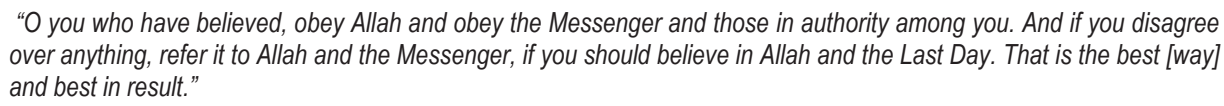

Shihab (2010) states that in sura Âli 'Imrān verse 35, I explained that if we note to the Qur'anic verses that ordered to obey Allah and His Messenger, we can found two different terms. First, obedience to Allah coupled with obedience to His Messenger without repeating the word ați ${ }^{i} u$ (obey). Second, the word ațí $u$ was repeated and every once referring to Allah and also to His Messenger, as in Sura al-Nisā' verse 59. The Qur'anic experts explain that when a command to obey Allah and His Messenger was combined with this word in once time, it means that the obedience is commanded by Allah, either stated in the Quran directly or it was described by the Prophet through his tradition. However, the obedience command to the Prophet here relates to the matters that come from Allah, and not directly commanded by the Prophet. When the command is repeated as found in Sura al-Nisā' verse 59 above, the Prophet has a right to be obeyed even if there is no essence in the Qur'an. Therefore, the command to obey the leaders (üli al-amri) does not accompanied by the words ați $u$, due to they do not have the right to be obeyed when had a conflict with the obedience to Allah and His Messenger. ${ }^{10}$

Based on the above it could be understood that the word ați ${ }^{\top} u$ in the Qur'an has two shape terms. First, the command to obeying Allah that coupled with obedience to His Messenger as found in sura Âli IImrān verse 35.11 Second, the word ațí'u was repeated whether referring to Allah or His Messenger, as in Sura al-Nisā' verse 59. Hence, to strengthen his exegesis, Shihab (2010) quoting the Qur'anic experts (without specifying who the expert was intended). Consequently, obeying the command of the Prophet is Allah's command directly and not sourced from the Prophet. Moreover, when the word attíu was repeated twice, then this command was not from Allah directly. However, the Prophet still has the right to be obeyed due to obedience to Allah could be applied through obedience to His Messenger.

Thus, these matters were different with the command to obey the leaders, due to they have no right to be obeyed if contrary to obedience to Allah and His Messenger. Accordingly, this study found that Shihab's exegesis was indicated also by al-Sha'rāwī (1995) and al-Jawziyyah (2003) in their exegetical books.

\footnotetext{
7 See also Shihab's exegesis that applied this rule in suras al-Baqarah 2: 216, al-Māidah 5: 52 and al-Tahrīm 66: 5.

${ }^{8}$ The word of 'asā was mentioned in the Qur'an in 26 verses ('Abd al-Bāqi 1945). And 13 verses referring to human beings, namely alBaqarah 2: 216, al-Nisa' 4: 19, al-A'rāf 7: 185, al-Tawbah 9: 18, Joseph 12: 21, al-lsrā' 17: 51 \& 79, al-Kahfi 18: 24, Maryam 19: 48, alNaml 27: 72, al-Qașaș 28: 9 \& 67 and al-Hujurāt 49: 11.

While the other 13 verses refer to God, as in sura al-Nisā' 4: 84 \& 99, al-Mā'idah 5: 52, al-A'rāf 7: 129, al-Tawbah 9: 102, Joseph 12: 83 , al-Isrā' 17: 8, al-Kahfi 18: 40, al-Qașaș 28: 22, al-Mumtaḥanah 60: 7, al-Tahrīm 66: 5 \& 8, and al-Qalam 68: 32.

Based on these facts, the authors suspect that Shihab was confused in his quote when interpreting sura al-Mumtahanah verse 7. Due to sura al-Baqarah verse 16 that was made by him as an example does not use the word 'asā. And sura al-Baqarah verse 216 is the highly possibility that Shihab was meant.

${ }^{9}$ This rule is a pure product of the authors which based on Shihab's exegesis in sura al-Nisā' verse 59. The authors did not find any scholar who claimed this rule related to the word of obey (ați 'ī) in the Qur'an, except their interpretations on the verses.

10 See also Shihab's exegesis that applied this rule in suras Āli 'Imrān 3: 32 and al-Mā'idah 5: 7.

11 The study suspects an error of writing in Shihab's exegesis above; due to sura Āli 'Imrān verse 35 does not use the word ațīu. However, it is likely that Shihab was meant by sura Āli 'Imrān verse 32 below: Say, "Obey Allah and the Messenger." But if they turn away - then indeed, Allah does not like the disbelievers."
} 


\subsection{RULE: Do not exegeting the Qur'anic words with synonymous meanings.}

The above rule was specified by al-Sabt (2001) and was supported by al-Qaraḍāwī (2001) which his statement that the Qur'an mentions the words with multiple meanings, but is limited to the context of the verse which makes it in one meaning by different words. Such things are not meant to be synonymous that contain one meaning, like the word qa'ada and jalasa (seat), surra and fariha (happy). It is merely expression of one thing or meaning in different words. Thus, after a detailed analysis conducted shows that each of words had a specific meaning. As a result, al-Jāhiz (1968) insists that the mistake is often made by people due to equate the meaning of the two words, then choose the meaning that is rarely used by Qur'an and at the same time leave the meanings that are often used by Qur'an. ${ }^{12}$

Shihab (2010) in his exegetical book also apply this rule, especially when interpreting sura al-Nisā' (The Women) verse 112 as following:

"But whoever earns an offense or a sin and then blames it on an innocent [person] has taken upon him-self a slander and manifest sin."

Shihab (2010) states that the word of khatii'ah usually defined by unintentional mistakes. However, due to the above verse using the word yaksibu (earn), then it shows that unintentional mistake was made because of slackness or lack of attention and attitude are not responsible culprit. There is also who understand the word khați ah is a sin that does not involve others, like leaving the duty of prayer, fasting, or doing something illegal, such as eating foods that are forbidden. The verse ithmān (sin) is understood as the sins that affect other people, such as murder or steal. ${ }^{13}$

Based on this explanation, the authors found that Shihab was applying the rule above. Shihab interprets the words khați ah and ithmān with different purposes, although it intrinsically refer to the same meaning, namely sin. In this case, the word khați ah as the sin that does not involves others, while ithmān is the sin that involves other people, such as murder or steal. However, there are a few things from this interpretation that need to be purified, namely:

i. The word of khatīiah according to Shihab is usually defined by an innocent mistake is not true. Thus, al-Tabarī (2001) stated that khațíah means the committed sins whether intentional or not, while ithmān refers to deliberate sin.

ii. Shihab's interpretation stating that the word of khați ${ }^{\top} a h$ refers to the act of sin that does not involve others, like leaving the duty of prayer, fasting, or doing something illegal, such as eating foods that are forbidden also need to be purified. The examples mentioned by him were inherently involve other people, even including from major sins, which left the prayer, fasting and eating food that is illegal. However, this interpretation is inconsistent with the 'Āshūr (1984) which states that the word of khațīah refers to small vices, while ithmān refers to the great vices.

iii. Shihab's interpretation to the word ithmān as a sin that affects others, such as murder or steal was conflict with other exegetes. Al-Baghāwī (1997) for example, states that the word of khațīah in the above verse refers to the meaning of theft, while ithmān refers to the commitment lies.

\section{Conclusion}

Shihab has stressed the importance to understanding the meaning of verses based on linguistic analysis. Those interests are accepted by him in applying the rules of exegesis in his book, Tafsir Al-Mishbah. Accordingly, this study found five rules were applied by him especially in regarding to the meaning of Qur'anic words. This effort to ensure his exegetical work is in accordance to the requirements of Islamic laws. In the five rules applied by Shihab were certainly recognized and articulated by scholars and exegetes, but in the fourth rule; this study shows that not found any scholars who stated on this rule clearly, but their exegesis of the verse only.

However, the study also found that Shihab absolutely consistent in applying the rules that have been discussed, but on the first rule. He was found to be inconsistent in applying it, especially when interpreting sura Äli 'Imrān, verse 27. Due to Shihab tends to the metaphorical or unpopular meaning, while the other exegetes tend to the real meaning. By doing that, his exegesis put forward by him was crippled. Thus, hopefully this brief analysis is able to open the eyes for a

12 One example was mentioned by al-Jāhiz (1968) is the word al-mațar and al-ghayth which are often referred by Arabs as rain. Whereas al-mațar used by Qur'an in the context of punishment (see al-Nisā, 4: 102). While the word of al-ghayth in the Qur'an always correlated with the grace of Allah (see al-Shūrā 42: 28).

13 15. See also Shihab's exegesis that applied this rule in suras Āli 'Imrān 3: 18 \& 146, al-Mā'idah 5: 3, al-An'ām 6: 1 and al-'Alaq $96: 1$ \& 2. 
wider analysis to the contents of his exegetical book that his inconsistent exegesis could be more transparently and known by the society.

\section{References}

'Abd al-Bāqī, M. F. (1945). Al-Mu'jam al-Mufahras li Alfāz al-Qur'ān al-Karīm. Cairo: Dār al-Hadīth.

'Āshūr, M. T. (1984). Al-Tahrīr wa al-Tanwīr. Vol. 5. Tunisia: Dār Sahnnūn.

Al-Baghāwī, M. H. (1997). Ma‘ālim al-Tanzīl fî Tafsīr al-Qur'ān. Vol. 2. Beirut: Dār Ihyyā' al-Turāth al-'Arabī.

Al-Fayūmī, M. A. (1990). Al-Mișbāḥ al-Munīr fì Gharīb al-Sharḥ al-Kabīr. Beirut: Maktabah Lubnān.

Ibn ‘Ațiyyah, A. M. (2001). Al-Muharrar al-Wajīz fi Tafsīr al-Kitāb al-'Azīz. Vol. 1. Beirut: Dār al-Kutub al-'Ilmiyyah.

Ibn Kathīr, I. (2000). Tafsīr al-Qur'ān al-'Azīm. Vol. 3. Egypt: Mu'assasat Qurțūbah.

Ibrahim, M. \& Usman, A. U. (2013a.). M. Quraish Shihab's thought about adulterer and thief in Tafsir Al-Mishbah: A critical analysis. Australian Journal of Basic and Applied Sciences, 7(4), pp. 63-67.

Ibrahim, M. \& Usman, A. U. (2013b.). Rules of M. Quraish Shihab exegesis in Tafsir Al-Mishbah. World Journal of Islamic History and Civilization, 3 (3): 101-108. http://dx.doi.org/10.5829/idosi.wjihc.2013.3.3.3303.

Ibrahim, M. \& Usman, A. U. (2013c.). The Rule of Interpretation: A Comparative Study between M. Quraish Shihab With al-Tabari. Advances in Natural and Applied Sciences, 7(1), pp. 15-22.

Al-Jāhịiz, A. U. (1968). All-Bayān wa al-Tabyīn. Beirut: Dār al-Ṣa'b.

Al-Jawziyyah, I. Q. (2003). al-Daw' al-Munīr ‘Ālā al-Tafsîr. Vol. 2. Riyadh: Maktabat Dār al-Salām.

Al-Jurjānī, A. M. (1985). Al-Ta'rifāt. Vol. 1. Beirut: Dār al-Kitāb al-Mu’āșirir.

Al-Kafawī, A. B. (1998). Al-Kulliyāt. Beirut: Mu'assasat al-Risālah.

Muhammad Khiḍr, I. (2009). Mabāhith fĩ Ușūl al-Tafsīr. Cairo: Dār al-Ṣafwah.

Ibn al-Wazīr, M. I. (1987). Ithār al-Ḥaq 'Ālà al-Ḥaq fĩ Rad al-Khilāfät ilā al-Mazhab al-Haq min Ușūl al-Tawhīd. Beirut: Dār al-Kutub alcllmiyyah.

Naja, M. S. (2007). Konsep Khalifatullah Dalam Perspektif M. Quraish Shihab Sebagai Kepemimpinan Pengembangan Pendidikan Islam. Unpublished Thesis. Deparment of Education. Faculty of Islamic Studies. The State Islamic University of Malang.

Al-Qaraḍāwī, Y. (2001). Kayfa Nata‘āmal Ma'a al-Qur'ān al-'Ażīm. Beirut: Dār al-Shurūq.

Al-Qurțubī, A. M. (1964). Al-Jāmi 'li Aḥkām al-Qur'ān. Vol. 2. Cairo: Dār al-Kutub al-Mișriyyah.

Riḍā, M. R. (1990). Tafsīr al-Manār. Vols. 1 \& 2. Cairo: al-Hay'ah al-Mașriyyah Li al-Kutub.

Al-Rūmī, F. (1999). Buhūuth fï Ușūl al-Tafsīr wa Manāhijuhu. Cairo: Maktabah al-Tawbah.

Al-Sa'dī, A. N. (1999). Al-Qawāid al-Hisān fî Tafsirir al-Qur'ān. Riyadh: Maktabah al-Rushd.

Al-Sabt, K. U. (2001). Qawāíld al-Tafsîr: Jam‘an wa Dirāsatan. Vol. 1. n.p.: Dār ibn 'Affān.

Al-Shanqițī, M. A. (1995). Aḍ̛wā’ al-Bayān fi Ị̇āḥ al-Qur'ān bi al-Qur'ān. Vol. 8. Beirut: Dār al-Fikr.

Al-Sha'rāwīi, M. (1995). Tafsìr al-Sha'rāwī. Vol. 3. Cairo: Akhbār al-Yaum.

Al-Shawkānī, M. A. (1993). Fatḥ al-Qaḍir al-Jāmi' Bayna Fannay al-Dirāyah wa al-Riwāyah min 'Ilm al-Tafsīr. Vol. 2. Cairo: Dar alHadith.

Shihab, M. Q. (2011a.). Membumikan al-Qur'an jilid 2: Memfungsikan wahyu dalam kehidupan. Jakarta: Lentera Hati.

Shihab, M. Q. (2011b.). M. Quraish Shihab menjawab 1001 soal keislaman yang patut anda ketahui. Jakarta: Lentera Hati.

Shihab, M. Q. (2010). Tafsir Al-Mishah: Pesan, Kesan dan Keserasian Al-Quran. Vols. 2 \& 13. Jakarta: Lentera Hati.

Shihab, M. Q. (1992). Membumikan al-Quran: Fungsi Wahyu dalam Kehidupan Masyarakat. Bandung: Mizan.

Subhan, A. (1993). Menyatukan kembali al-Qur'an dan umat: Menguak pemikiran M. Quraish Shihab, Journal of Ulumul Quran, vol. 4, no 5 , pp. 10-12.

Al-Ṭabarānī, S. A. (1983). Al-Mu'jam al-Kabīr. Vol. 7. Beirut: Maktabah al-'Ulūm wa al-Ḥikam.

Al-Ṭabarī, J. (2001). Tafsīr al-Ṭabarī. Vols. 6 \& 9. Cairo: Markaz al-Buhūuth wa al-Dirāsah al-'Arabiyah wa al-Islāmiyyah.

Al-Tirmidhī, M. I. (2008). Al-Jāmi' al-Ṣahị̄h Sunan al-Tirmidhĩ. Vol. 5. Beirut: Dār lḥya' al-Turāth al-'Arabī.

Al-Zarkashī, B. M. (1988). Al-Burhān fì 'Ulüm al-Qur'ān. Vol. 3. Cairo: Dār al-Turāth. 